\title{
Low Anorectal Malformation
}

National Cancer Institute

\section{Source}

National Cancer Institute. Low Anorectal Malformation. NCI Thesaurus. Code C98975.

Congenital malformations in the anorectal region that include the perineal fistula, anteriorly placed anus, and anorecto-vestibular fistula. 